\title{
A review of river habitat characterisation methods: indices vs. characterisation protocols
}

\author{
Diego Fernández ${ }^{1, *}$, José Barquín ${ }^{1}$ and Paul J. Raven ${ }^{2}$ \\ ${ }^{1}$ Environmental Hydraulics Institute "IH Cantabria". Universidad de Cantabria, PCTCAN. C/Isabel Torres, 15. \\ Santander, Spain. \\ ${ }^{2}$ Environment Agency, Rio House, Waterside Drive, Aztec West, Almondsbury, Bristol, BS32 4UD, U.K. \\ * Corresponding author: fernandezgd@unican.es
}

Received: 10/6/2010

Accepted: 2/5/2011

\begin{abstract}
A review of river habitat characterisation methods: indices vs. characterisation protocols

A wide variety of methodologies have been proposed for characterising river habitats in order to meet different environmental objectives. However, mid- to long-term monitoring of the physical characteristics of river habitats lacks a standardised methodology. This contrasts with well-established methods for monitoring other river ecosystem components. Some attempts have been made to standardise the methods for characterising river habitats including the European Guidance Standard for Assessing the Hydromorphological Characteristics of Rivers (CEN, 2002) and the Physical and Chemical Assessment Module within the Australian River Assessment System (AusRivAS). One of the first steps toward advancing the development and use of methods for characterising river habitats in mid- to long-term monitoring programs is to review current practices so that deficiencies can be identified and addressed. In the present work, we review more than 50 methods that have been used to characterise river habitats worldwide. This review uses the European standard as a reference benchmark for comparison with existing methods of river habitat characterisation. Methods of characterising river habitats differ mainly with respect to three features: (1) the objectives for which they were designed, (2) the time required for their application and (3) whether they measure characteristics or evaluate them. Channel and riparian zone characteristics are more extensively covered than floodplain characteristics. Moreover, of all the described river habitat characteristics, bank stability, channel substrate, artificial structures, riparian vegetation structure, channel dimensions, flow types or flow status, adjacent land uses and bars are the most commonly recorded. We conclude that assessment methods of river habitat characteristics that gather quantitative information at a range of spatial scales could be the most effective, as they provide relatively extensive data sets that can be used to analyse information for several purposes. Finally, some types of rivers, such as intermittent rivers, require further work in order to identify their physical habitat characteristics and the proper monitoring methodology.
\end{abstract}

Key words: River habitat, habitat assessment, physical environment, hydromorphology.

\section{RESUMEN}

Revisión de los métodos de caracterización del hábitat fluvial: índices vs. protocolos de caracterización

Una gran variedad de metodologías se han propuesto para la caracterización de los hábitats fluviales a fin de cumplir con diferentes objetivos medioambientales. Esta diversidad de métodos puede ser vista como una ventaja para hacer frente a diferentes objetivos ambientales. Sin embargo, el seguimiento a medio o largo plazo de las características físicas del hábitat fluvial carece de una metodología estandarizada, lo cual contrasta con otros métodos mucho mejor establecidos para el seguimiento de otros componentes del ecosistema fluvial. Se han hecho algunos intentos para estandarizar los métodos de caracterización de los hábitats fluviales, y estos incluyen el estándar europeo para la evaluación de las características hidromorfológicas de los ríos (CEN, 2002), y el desarrollo del módulo de evaluación fisicoquímica dentro del sistema australiano de evaluación fluvial (AusRivAS). Uno de los primeros pasos para avanzar en el desarrollo y uso de métodos para la caracterización de los hábitats fluviales en los programas de seguimiento a medio y largo plazo es revisar las prácticas actuales a fin de poder abordar las deficiencias e introducir mejoras. En el presente trabajo se revisan más de 50 métodos que se han utilizado para caracterizar los hábitats fluviales en todo el mundo, utilizando el estándar europeo como referencia para comparar los métodos. Los métodos de caracterización de los hábitats fluviales se diferencian principalmente por tres 
razones: (1) los objetivos para los que fueron diseñados, (2) el tiempo que demanda su aplicación y (3) unos miden mientras otros evalúan las características del hábitat. Las características del cauce y de la zona ribereña son consideradas por un mayor número de métodos que las características de la llanura de inundación. Además, entre todas las características del hábitat fluvial descritas, la estabilidad de las orillas, el sustrato del lecho, las estructuras artificiales, la estructura de la vegetación ribereña, las dimensiones del cauce, el tipo de flujo o el caudal, los usos del suelo adyacentes y las barras de sedimentos son las más comúnmente registradas. Se concluye que los métodos de medición de las características del hábitat fluvial que recogen información cuantitativa cubriendo diferentes escalas espaciales podrían ser los más eficaces, ya que proporcionan bases de datos más amplias que permiten utilizar la información para diversos objetivos. Por último, algunos tipos de ríos, como los ríos intermitentes, requieren un mayor estudio para poder identificar correctamente los atributos físicos y la metodología adecuada para realizar el seguimiento de las características del hábitat.

Palabras clave: Hábitat fluvial, Evaluación del hábitat, Entorno físico, Hidromorfología.

\section{INTRODUCTION}

Physical habitat assessment is a common approach in geomorphic studies that aim to characterise the physical realm and to explain the processes involved in creating spatial heterogeneity and particular physical features (Smith, 1990; Butler, 1995). The characterisation of physical habitat elements is also fundamental in ecological studies that are designed to explain physical heterogeneity, distributional patterns of organisms, composition and structure of biological communities or ecosystem function. In fluvial geomorphology and ecology, physical habitat assessment is also extremely important for understanding how river ecosystems function.

River habitats have been defined as the local physical, chemical and biological features that provide environments for in-stream biota (Jowett, 1997). Physical characteristics of river habitats can be understood as a dynamic mosaic of hydromorphological features that result from the interaction between the discharge regime and the structural components of the river channel (Maddock, 1999). Thus, defining and characterising river habitats is a difficult task, as rivers are highly complex structured ecosystems, and river habitat characteristics can be described at different spatial and temporal scales (Frissell, 1986) and with different objects of study in mind (e.g., macrophytes or fish distribution patterns; Elosegi et al., 2011).
Despite the complexity of river habitats, a wide array of methodologies have been proposed for characterising these habitats at a range of spatial scales in order to meet different objectives (Mc Ginnity et al., 2005). The objective of a given method, for example, conservation, water resource management or the assessment of ecosystem integrity or geomorphic condition, determines the habitat attributes and diagnostics used (Raven et al., 2010). Although the diversity of methods might be seen as an advantage for tackling different environmental objectives, mid- to long-term monitoring of physical characteristics of river habitats lacks a standardised methodology, in contrast with the well-established methods for monitoring water quality and biological communities (Maddock, 1999). Moreover, scientific consensus on which methods to use and which river features to monitor is also far from unanimous because many fundamental questions relating hydrological, chemical and biological characteristics to river habitats remain unanswered (Vaughan et al., 2009). One of the main obstacles to progress in this field is the lack of mid- to long-term data collected following a standardised protocol, which would allow the comparison of physical characteristics of rivers among regions or at a continental level (e.g., Raven et al., 2010).

Some attempts have been made to standardise the methods for characterising river habitats. These include the European Guidance Standard 
for Assessing the Hydromorphological Characteristics of Rivers (CEN, 2002) and the Physical and Chemical Assessment Module within the Australian River Assessment System (AusRivAS; Parsons et al., 2004), the latter of which aimed to build a river habitat assessment methodology (workshop held at the University of Canberra on May 2-3, 2000). These individual initiatives show the importance of achieving a common approach to characterising river habitats, at least at a national level or even a continental level, so that attributes can be compared at different spatiotemporal scales. In other parts of the world, the implementation of different directives such as the Habitats Directive (HD: 92/43/CEE) and the Water Framework Directive (WFD: 2000/60/CEE) in Europe or the Clean Water Act (CWA; US Government 1977) and the Endangered Species Act in the USA (ESA; US Government 1973) could provide a good framework for gathering data on the physical characteristics of river habitats in a standardised way, but the scientific community must make a concerted effort to reach a consensus on which methodologies are best to use.

One of the first steps toward advancing the development and use of methods for characterising river habitats in mid- to long-term monitoring programs is to review current practices so that deficiencies can be identified and addressed. However, most reviews of the physical habitat assessment methods used in rivers covered few methods (Raven et al., 2002; Kamp et al., 2007; Weiß et al., 2008; Šípek et al., 2009) or lacked any comparison to an agreed standard (Mc Ginnity et al., 2005; Kamp et al., 2007; Šípek et al., 2009). In the present work, we review more than 50 methods that have been used to characterise river habitats worldwide. This review uses as a reference the European standard for assessing the hydromorphological characteristics of rivers (CEN, 2002), which constitutes one of the largest efforts to standardise the monitoring of the physical characteristics of river habitats (Boon et al., 2010). The main objectives of this review are to summarise existing methods for characterising river habitats for monitoring programs, to point out deficiencies and strengths, and to suggest possible implementation and future directions.

\section{METHODOLOGY}

For this review, we selected a wide spectrum of methods dealing with the characterisation of physical attributes in European, North American and Australian river habitats (Appendix I). We excluded methods that consider only aspects of the hydrological regime, methods that cover only the microhabitat scale and physical habitat simulation models (PHABSIM; Bovee et al., 1998), as these all differ considerably in structure and aims compared to methods that consider reachscale habitat characteristics. Independent studies of physical habitat characteristics in rivers are also not considered in this study; we focus instead on established methods that have the potential to be used or are being used to monitor physical characteristics of river habitats. Information was gathered for this review by searching for publications in the Science Citation Index and other reports available online. We also queried some authors directly when we were aware of their relevant studies. A total of 55 methods are included in this review, with almost $70 \%$ of the information extracted from original sources (Appendices I and II).

The present review uses the set of river habitat attributes outlined in the European standard for assessing the hydromorphological characteristics of rivers (CEN, 2002) as a baseline for comparison of the different methods. The review is structured around the comparisons of five general features across methods: (1) spatial scales, (2) coverage of river zones, (3) key physical features, (4) balance between resources and accuracy, and (5) applicability to different geographical areas.

\section{REVIEW OF METHODS}

The intention of this review is not to identify the best available method for monitoring the physical characteristics of river habitats but to provide a general review of the existing methods. There are three main differences among the methods reviewed. First, the selected methods have been designed to cover different objectives that range from geomorphological surveys to classification 
systems or evaluation of river corridors, and thus, they usually differ in the spatial scale they cover and the attributes they address. Second, many methods have been developed for rapid assessment in the field, and as a result, these methods yield lower quality data (i.e., categorical or qualitative data that are not as informative as quantitative data) or incomplete data about some attributes of the river habitat. Third, two kinds of methods are clearly distinguishable: those for measuring characteristics of a river's physical habitat and those for evaluating these characteristics. The former methods are designed for recording information about the presence, extent and distribution of a set of structural features (e.g., substrate size, bank profile and in-channel vegetation) and hydraulic features (e.g., water depth, water velocity and water surface pattern). In contrast, methods for evaluating river habitats provide an index or another type of rating based on qualitative or semi-quantitative information about the condition of the river habitat or a set of river habitat characteristics. These latter methods usually compare the existing situation to that expected to occur in a pristine or semi-natural state. Methods of characterising river habitats are usually more complete the greater the number of characteristics they record. More complete methods produce higher quality information (i.e., quantitative data) and have the potential to meet several scientific and management goals.

\section{Spatial scales}

River ecosystems have a hierarchical spatial organisation (Frissell et al., 1986; De Boer, 1992), and the structural characteristics of each level are governed by physical processes operating at the levels above. Only $40 \%$ of the reviewed methods (Tables 1 and 2 in Appendix II) gather data on large-scale variables, and, few of these methods (e.g., HIDRI and NAWQA) include a protocol for gathering and integrating catchment-level data. We believe this is due to the perception that large-scale catchment variables are less likely to be affected by human impacts and, thus, they are ignored in monitoring programs. However, large-scale variables provide a framework for the characterisation of lower-scale variables, and thus they allow us to define river types and to determine the local physical characteristics that are expected to be found in a given river reach (Parsons et al., 2004; Snelder et al., 2011). In this regard, river classifications based on large-scale variables could be used to structure the characterisation of lower-scale habitat variables. For example, Orr et al. (2008) developed a predictive, hierarchically organised typology for British rivers using variables related to network position (stream order and specific stream power) and topography (slope and presence of floodplain). The obtained river types were distinguished by channel morphology characteristics and erosion/deposition processes. Other widely used typologies are the Rosgen classification (Rosgen, 1994) and River Styles (Brierley \& Fryirs, 2000; Brierley \& Fryirs, 2005), which rely on the characterisation of river attributes from the catchment scale to the reach scale. River habitat characterisation is generally missing an important set of medium- to large-scale characteristics related to the valley and river network structure (e.g., river valley width, side valley slopes, tributary effects and channel density) that have important effects on river habitat characteristics at the segment and reach scales (Benda et al., 2011).

The great majority of existing methods are designed to gather information on river habitats at the reach scale. While data on large-scale variables are usually obtained from existing sources such as maps or databases of remotely-sensed information, variables at reach or lower scales require field surveys or modelling for proper characterisation. The length of the river reach can be considered as fixed and never greater than one kilometre (e.g., HCI, RHS, DSFI and $\mathrm{NPHI}$ ) or variable and based on river width or changes in geomorphic variables (e.g., Qualphy, RSR, SRS, EcoRivHab and AusRivAs). Some of these methods are supplemented with GIS or remote-sensing techniques to determine river reach lengths or to record large-scale variables such as upstream catchment area or distance from the source. For example, AusRivAS (Parsons et al., 2004) and the River Habitat Survey (Raven et al., 1997; Raven et al., 1998), 
which are two of the most widely used methods at the reach scale, include at least some variables at the valley, reach and mesohabitat scales. AusRivAS combines survey and GIS techniques, including both large- and medium-scale characteristics, whereas the RHS completely lacks a protocol for gathering information at the segment or catchment scales.

\section{Surveyed river zones}

Most $(95 \%)$ of the methods included in this review survey the river channel, and most (93\%) also include the banks and riparian zones. Floodplains are excluded more often than the other river zones (in $27 \%$ of the methods). Methods that use remotely-sensed information usually include features throughout the floodplain, while methods that rely on information gathered by walking along the river bank or channel cannot be used to record features beyond the surveyor's sight. To address this issue, the River Habitat Survey has been supplemented with GeoRHS (Branson et al., 2005) a method for analysing floodplain geomorphology and its connection with the river channel based on both a field survey and remotely-sensed information.

Some of the reviewed methods are specifically designed for the assessment of a single river zone. Examples include the Riparian Quality Index (RQI; González del Tánago \& García de Jalón, 2011), the Riparian Forest Quality Index (QBR; Munné et al., 2003) and the Riparian Forest eValuation index (RFV; Magdaleno et $a l ., 2010)$, which are used for evaluating riparian conditions, and the River Habitat Index (IHF; Pardo et al., 2002) which assesses the heterogeneity of in-channel physical elements. In other cases, a single method integrates different indices or metrics in its evaluation of physical habitat characteristics. Examples are the Habitat Condition Index (HCI; Oliveira \& Cortes, 2005), which is composed of ten variables including the QBR, and the HIDRI protocol (ACA, 2006), which uses a number of metrics including as the Index of Fluvial Connectivity (ICF; ACA, 2006; Solà et al., 2011), the level of embankment (END; ACA, 2006), the QBR and others.

\section{Physical features}

Methods for characterising river habitats vary considerably in the set of structural and hydraulic features recorded in order to achieve different goals. The characteristics that these methods record can be grouped according to the relevance of the method for: (i) determining patterns in river habitats, (ii) providing information about ecosystem function and processes, (iii) determining the factors that influence patterns in biological communities, (iv) assessing impairment caused by hydro-morphological pressures and (v) complying with applicable environmental legislation. The most commonly recorded features are: bank stability ( $80 \%$ of methods), channel substrate $(78 \%)$, artificial structures $(75 \%)$, riparian vegetation structure $(76 \%)$, channel dimensions (69\%), flow types or flow status $(65 \%)$, adjacent land-uses (64\%) and bars (62\%). In contrast, bank material (36\%), channel vegetation $(51 \%)$ and woody debris $(51 \%)$ are less commonly recorded by river habitat characterisation methods. All of these characteristics appear on average in $67 \%$ of the European methods and in $62 \%$ of the North American and Australian methods and are related to goals (i)-(iii) above.

Artificial structures and human land use, along with features that reflect impacts on sediment mobility (armouring and embeddedness), provide information about the degree of habitat modification. Only five of the 29 European methods included in our review do not record artificial structures (IHF, RFV, DSFI, NPHI and physSC), whereas this number is higher for the North American and Australian methods (nine methods), mainly because the latter contain methods developed for river or catchment characterisation and classification (e.g., HPM, RHPI, RS and GRS). Artificial features are extensively evaluated by the IHG index (Ollero et al., 2011), which assesses river hydro-geomorphological dynamics using aerial photographs, maps, hydrologic data and field observations. The recording of artificial structures also provides essential information for river management as well as data for improving our knowledge about the impacts that these structures have on physical habitats. As the impacts 
of hydromorphological pressures are not always well known and effects might be noticed far from the structure or activity, it is very important to record other physical characteristics that are sensitive to changes caused by these pressures. As an example, upstream from a dam, the substrate becomes finer and the flow slower, whereas downstream there are usually faster flows and coarser substrates. Therefore, flow type and substrate are two attributes that can provide information about a pressure located outside of the stretch of river under study, if the stretch is analysed in the context of its basin and river type.

In Europe, current environmental legislation affecting river ecosystem management includes the Water Framework Directive (WFD) and the Habitats Directive (HD). The WFD focuses on three elements of hydromorphological quality, the first of which is the hydrological regime. Although many of the reviewed methods consider discharge, most of them assess only flow at the time of survey, and only some (e.g., AusRivAS, IHG, SEQ-P and ISC) assess the naturalness of the hydrological regime. The second element addressed by the WFD is river continuity, which is assessed by recording artificial structures and activities that disturb the migration of aquatic organisms and sediment transport. The third WFD element concerns morphological conditions of the river as described by channel patterns, width and depth variations, flow velocities, substrate conditions and both the structure and condition of riparian vegetation. Whereas most of these attributes are considered by the majority of methods for assessing river physical habitat, variations in width and depth are frequently omitted, and to our knowledge, only HIDRI, PHCEMAP, MPCA and BURP take both of them into account, although width variation is also considered in a modification of the RHS form in Italy (Buffagni \& Kemp, 2002). Under the Habitats Directive, conservation status is defined as the sum of the relevant influences acting on a natural habitat and its species. Therefore, the physical characteristics of the river habitat must be considered in a conservation status assessment (Barquin et al., 2012), although the directive does not specify the attributes to be considered. One ap- proach to this issue is to use habitat characterisation methods that consider the key river habitat requirements of the different species and vegetation communities listed in Appendix II of the $\mathrm{HD}$, although at present almost all methods consider biological communities in a wider sense.

\section{Resources versus accuracy}

The sources of information and the way in which information is gathered are two crucial factors that must be taken into account to achieve a costeffective monitoring program that yields reliable information. Methods based only on databases (maps or databases of remotely-sensed information), such as LAWA-OS (LAWA, 2002), usually consume much less time and fewer resources than those based on field surveys, and they are better at gathering information about large scale variables. Database methods are also good for providing an overview of the hydromorphological character of large areas, but they tend to overestimate or underestimate "quality" compared with field survey methods (Weiß et al., 2008, Matoušková \& Dvořák, 2011). The use of remote sensing techniques such as LiDAR (Light Detection and Ranging) is more accurate and useful for assessing certain reach-scale variables such as the longitudinal, transversal and vertical continuity of riparian forests (Magdaleno et al., 2010). However, LiDAR data and most high resolution satellite images are still very expensive. Currently, information about variables at the reach scale and lower spatial scales is usually obtained by methods based on field surveys. However, some survey methods (approximately $60 \%$ of those reviewed here) have been developed as quick assessment techniques at the expense of information quality (i.e., data are not measured quantitatively) or completeness (i.e., some attributes of the physical habitat or riverine zones are ignored).

Regarding the approach to data recording, some methods record information on physical structures as they occur (e.g., NAWQA and BURP) whilst others produce a score related to the quality or quantity of certain parts of the physical habitat (e.g., IHF, HCI and HABSCORE). The first approach usually requires more time but is less sub- 
jective and allows subsequent analysis of the information for other purposes and even for index development if needed. Mapping physical characteristics along the river channel, as is done in the Mesohabitat Approach (Tickner et al., 2000), yields very detailed information about the extent, location and distribution of features. In some cases, mesohabitat mapping can cover multiple kilometres in a day (Mouton et al., 2011), although this depends on the number of river characteristics measured and the type of information gathered. One of the greatest benefits of methods that yield quantitative or semi-quantitative data is that they can be productively combined with modelling techniques (Booker et al., 2004).

\section{Applicability}

The key physical characteristics that should be considered when monitoring river habitats and the way in which the information is best gathered depend on the river type. Thus, providing a single protocol for monitoring river habitats is a difficult task. Not including river-type-specific characteristics in a protocol increases generality such that protocols can be applied to different geographic areas, but decreases accuracy because some important attributes are omitted. Most of the existing methods have been developed for application to a specific geographic area or within a particular river type, and their use under other conditions requires adaptations that include local or type-specific characteristics. In this regard, more than $95 \%$ of the methods cover onechannel permanent rivers and streams, although $33 \%$ of the methods are also valid for braided channels. In addition, $73 \%$ of the methods are designed for application to wadeable rivers, $2 \%$ are specific for non-wadeable rivers and $25 \%$ can be used for both types. Some methods distinguish coarse river typologies, and these define a different protocol for each river type. For example, the HABSCORE method (Plafkin et al., 1989; Barbour et al., 1999) classifies rivers into high-gradient streams and low-gradient streams, and RHVSH-EMAP (Lazorchak et al., 1998) distinguishes between riffle/run or pool/glide prevalence. The QBR index uses a similar concept, al- though it maintains a single protocol in which the score of some attributes is dependent on the river type. Other methods have been recently proposed for application to rivers with special characteristics, such as: (i) the North American Non-Wadeable Habitat Index (NWHI; Wilhelm et al., 2005), which is specifically designed for large rivers, (ii) the Italian adaptation of the RHS method to Southern European rivers (Buffagni \& Kemp, 2002), which fits braided and temporary streams by including some common features for these types of rivers, (iii) the Urban River Survey (URS; Davenport et al., 2004), which is an extension of the original RHS for rivers running through urban areas and (iv) a recent development to incorporate some riparian attributes into the core of the RHS methodology for rivers in Southern Portugal (Raven et al., 2009). Seasonal or intermittent rivers commonly found in Mediterranean areas require adaptations or different methodologies than those reviewed here, as none of the reviewed methods were specifically developed for application to temporary streams. However, nearly $10 \%$ of the reviewed methods are suggested to be applicable to both permanent and intermittent rivers.

\section{Towards a standardisation}

The European Standard for Assessing the Hydromorphological Features of Rivers (CEN, 2002) covers all of the WFD requirements concerning river continuity and morphological conditions. The HIDRI, RHS, Qualphy, SEQ-P, IFF, WatercSt, LAWA-FS and EcoRivHab methods in Europe, and SRS, AusRivAs, NAWQA, WSAss and VSGA methods in Australia and USA (Fig. 1) record many of the CEN standard attributes. These methods are based on field surveys, but they all have the potential to include large-scale information (e.g., from aerial photographs or maps). All of them consider in-stream, bank, riparian and floodplain zones and can be applied to meet different objectives, although onsite assessment methods that almost exclusively record category-based information (such as SEQMP and LAWA-FS) are more limited in this respect. When different methods are applied 


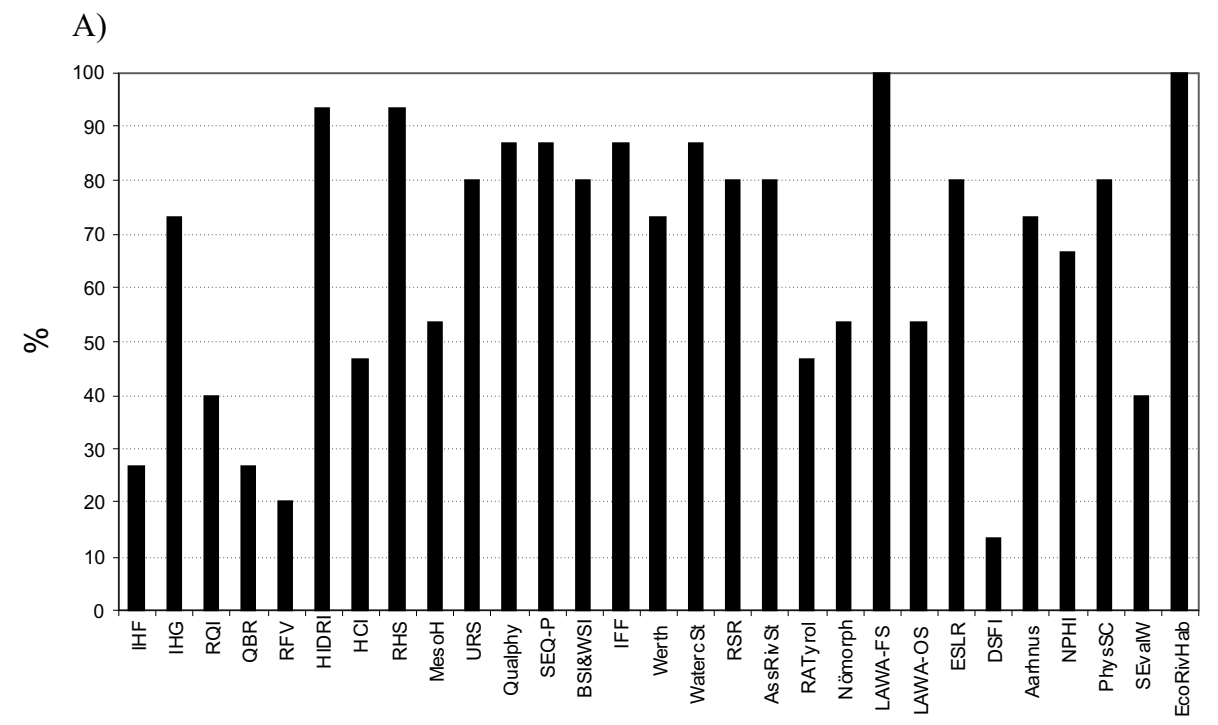

B)

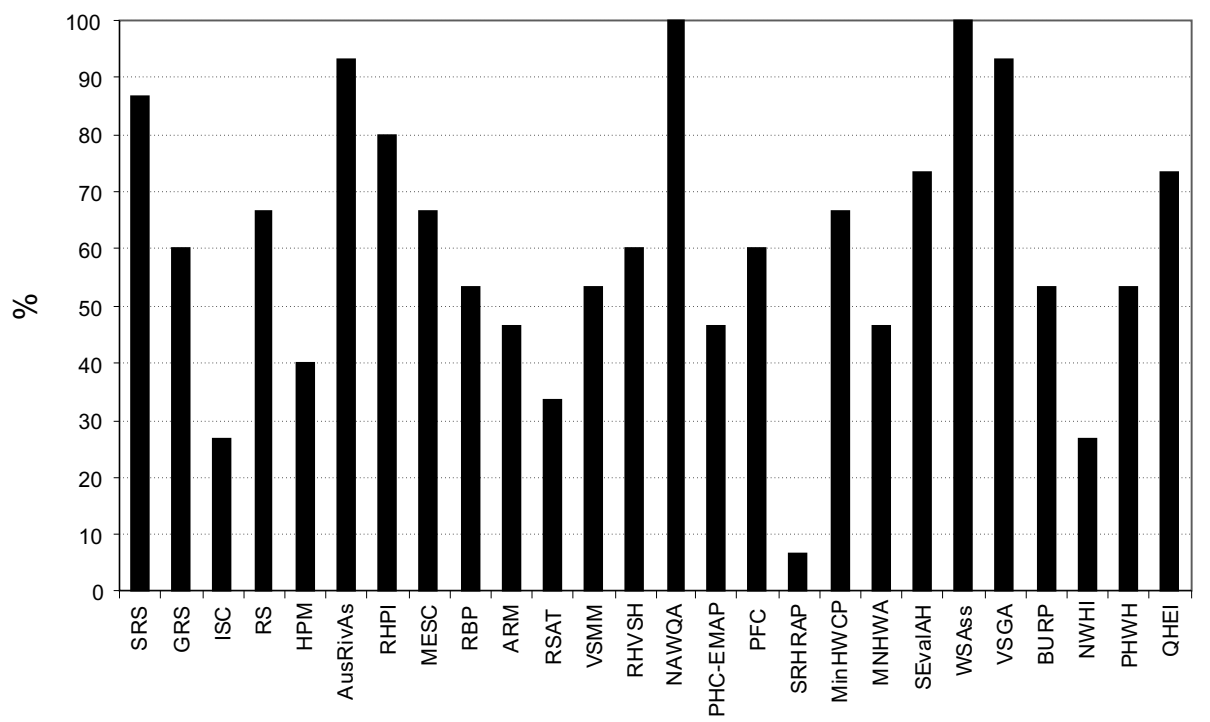

Figure 1. Percentage of the river habitat features described in the CEN standard (2002) that are recorded in European (A) and North American and Australian (B) habitat assessment methods. Porcentaje de características del hábitat fluvial descritas en el estándar CEN (2002) registradas por los métodos de evaluación del hábitat físico de Europa (A) y de Norteamérica y Australia (B).

to each riverine zone, as occurs in IHF (channel characteristics) or RQI and QBR (riparian zone), these need to be integrated in a protocol such as HIDRI to provide a complete characterisation of all river zones. We found little information about SRHRAP, MNWHA, SEvalAH and WSAss, so in Figure 1B, these methods do not appear to address many of the CEN standard pro- posed attributes. Despite this, it seems that European methods usually cover more habitat characteristics than those developed in North America, mainly because some of the American methods have been developed for stream classifications or to obtain a rapid assessment in the field in combination with biological surveys (e.g., RBP, RSAT, RHVSH-EMAP and SRHRAP). 


\section{CONCLUSIONS AND FURTHER CONSIDERATIONS}

Our review has identified the main differences in several methods of river habitat characterisation and the main reasons for those differences. We conclude that the CEN guidance standard for assessing the hydromorphological characteristics of rivers provides a good model for the set of physical features that should be recorded for monitoring river habitat characteristics, although it is less clear how to proceed from here.

Those methods that measure river habitat characteristics and gather higher quality information seem to be more effective than evaluation methods, as they provide a more extensive database that can be used to analyse information for several purposes, including the assessment of a river's physical condition. Moreover, many reach-scale methods for the characterisation of a river's physical habitat are qualitative or semi-quantitative, providing a subjective score on a group of physical habitat characteristics and not quantifying the presence or absence of certain physical characteristics or their relative importance. A more detailed description of the location and distribution of the different physical habitat characteristics is needed both for the definition of proper reference conditions and to reveal temporal variation in these characteristics (Raven et al., 2010).

In addition, proper quantification of physical habitat characteristics in rivers is necessary for understanding the physical processes that shape physical habitat composition and structure. Complete and accurate data are especially important for studying cause-effect relationships and the cumulative effects that human activities have on stream physical habitat from the catchment to the microhabitat scale (Vaughan et al., 2009). Quantification of physical habitat characteristics in rivers is also needed for establishing reliable predictive models of habitat suitability for different biological organisms in the framework provided by legislation and other biological conservation goals worldwide. Advances in the characterisation and assessment of physical habitat attributes in rivers need to take into account the hierarchical spatial scales of physical processes in rivers, incorporating these into the quantification of physical habitat characteristics and paying special attention to which and how large-scale variables are included. Finally, further work is required to identify the set of habitat characteristics that should be monitored in seasonal and intermittent rivers and the methodology by which this should be done.

\section{ACKNOWLEDGEMENTS}

We thank the many people of the IH-Cantabria who helped at various stages of this study from data compilation to the initial analyses. This study has been funded in part by the Spanish Ministry of Science and Innovation in relation to the project MARCE (Ref: CTM-2009-07447). We also thank the two anonymous reviewers whose comments helped improve earlier drafts of this paper.

\section{REFERENCES}

ACA. 2006. Protocolo para la valoración de la calidad hidromorfológica de los ríos (protocolo HIDRI). Agencia Catalana del Agua (ACA). 160 pp.

ADTL. 1996a. Fließgewässeratlas Tirol-Bachmorphologische und nutzungsorientierte Inventarisierung. Bezirk Kufstein. Amt Der Tiroler Landesregierung, Abteilung Wasserwirtschaft, Innsbruck, Austria. $98 \mathrm{pp}$.

ADTL. 1996b. Fließgewässeratlas Tirol-Bachmorphologische und nutzungsorientierte Inventarisierung. Bezirk Kitzbühl. Amt Der Tiroler Landesregierung, Abteilung Wasserwirtschaft, Innsbruck, Austria. $90 \mathrm{pp}$.

AGENCES DE L'EAU \& MINISTÉRE DE L'ENVIRONNEMENT. 1998. SEQ-Physique: a system for the evaluation of the physical quality of water-courses. Agences de l'Eau \& Ministère de l'Environnement. Paris. 15 pp.

ANDERSON, J. R. 1993. State of the Rivers Project. Department of Primary Industries, Queensland.

BARBOUR, M. T., J. GERRITSEN, B. D. SNYDER \& J. B. STRIBLING. 1999. Rapid bioassessment protocols for use in streams and wadeable rivers: periphyton, benthic macroinvertebrates and fish, Second Edition. USEPA 841-B-99-002. United 
States Environmental Protection Agency. Washington D.C. 339 pp.

BARQUÍN, J., B. ONDIVIELA, M. RECIO, M. ÁLVAREZ-CABRIA, F. J. PEÑAS, D. FERNÁNDEZ, A. GÓMEZ, C. ÁLVAREZ \& J. A. JUANES. 2012. Assessing the conservation status of alder-ash alluvial forest and Atlantic salmon in the Natura 2000 river network of Cantabria, Northern Spain. In: River conservation and management. P. J. Boon \& P. J. Raven (eds.): 191-208.WileyBlackwell.

BENDA, L., D. MILLER \& J. BARQUÍN. 2011. Creating a catchment perspective for river restoration. Hydrology and Earth Systems Sciences, 8: 2929 2973.

BOOKER, D. J., M. J. DUNBAR, M. C. ACREMAN, K. AKANDE \& C. DECLERCK. 2004. Habitat assessment at the catchment scale; application to the River Itchen, UK. In: Hydrology: Science and Practice for the 21 st Century, Volume II. B. Webb, M. Acreman, C. Maksimovic, H. Smithers \& C. Kirby (eds): 10-18. Proceedings of the British Hydrological Society International Conference July 2004.

BOON, P. J., N. T. H. HOLMES \& P. J. RAVEN. 2010. Developing standard approaches for recording and assessing river hydromorphology: the role of the European Committee for Standardization (CEN). Aquatic Conservation-Marine and Freshwater Ecosystems, 20: S55-S61.

BOVEE, K. D., B. L. LAMB, J. M. BARTHHOLOW, C. B. STALNAKER, J. TAYLOR \& J. HENRISKEN. 1998. Stream habitat analysis using the instream flow incremental methodology. U.S. Geological Survey, Biological Resources Division Information and Technology report USGS/BRD1998-0004. $131 \mathrm{pp.}$

BRAIONI, M. G., P. DE FRANCESCHI, A. BRAIONI, G. CAMPEOL, S. CALOI, N. GRANDIS, A. PONTIROLI \& P. RAVANELLO. 2001. New environmental indices for assessing bank quality in the restoration and the sustainable management of a river: the method. Ecohydrology \& Hydrobiology, 1(1-2): 133-154.

BRANSON, J., C. HILL, D. D. HORNBY, M. D. NEWSON \& D. A. SEAR. 2005. A refined geomorphological and floodplain component of River Habitat Survey (GeoRHS). Environment Agency, Bristol. 115 pp.

BRIERLEY, G. J. \& K. A. FRYIRS. 2005. Geomorphology and River Management: Applications of the River Styles Framework. Blackwell Publishing. Oxford, UK. 398 pp.

BRIERLEY, G. J. \& K. FRYIRS. 2000. River Styles, a geomorphic approach to catchment characterization: Implications for river rehabilitation in Bega catchment, New South Wales, Australia. Environmental Management, 25: 661-679.

BRIERLEY, G. J., K. FRYIRS \& T.COHEN. 1996. Development of a generic geomorphic framework to assess catchment character. Part 1. A geomorphic approach to catchment characterisation. Working Paper 9603, Macquarie University, Graduate School of Environment. 53 pp.

BUFFAGNI, A. \& J. L. KEMP. 2002. Looking beyond the shores of the United Kingdom: Addenda for the application of River Habitat Survey in Southern European rivers. Journal of Limnology, 61(2): 199-214.

BUHMANN, D. \& G. HUTTER. 1996. Fließgewässer in Vorarlberg. Gewässerstrukturen ErfassenBewerten-Darstellen. Ein Konzept. Schriftenreihe Lebensraum Vorarlberg. Band 33. Bregenz (Austria). $61 \mathrm{pp}$.

BURP TAC. 2004. Beneficial use reconnaissance program field manual for streams. Beneficial Use Reconnaissance Program Technical Advisory Committee, Idaho Department of Environmental Quality. Boise, ID.

BUTLER, D. R. 1995. Zoogeomorphology: animals as geomorphic agents, Cambridge University Press. $231 \mathrm{pp}$.

CEN. 2002. A guidance standard for assessing the hydromorphological features of rivers. CEN TC 230/WG2/TG 5: N32. 21 pp.

CROWE, E. \& G. KUDRAY. 2003. Wetland assessment of the Whitewater watershed. Report to U.S. Bureau of Land Management, Malta Field Office. Montana Natural Heritage Program, Helena, MT. $43 \mathrm{pp}$.

DAVENPORT, A. J., A. M. GURNELL \& P. D. ARMITAGE. 2004. Habitat survey and classification of urban rivers. River Research and Applications, 20: 687-704.

DAVIES, N. M., R. H. NORRIS \& M. C. THOMS. 2000. Prediction and assessment of local stream habitat features using large-scale catchment characteristics. Freshwater Biology, 45: 343-369.

DE BOER, D. H. 1992. Hierarchies and spatial scale in process geomorphology: a review. Geomorphology, 4(5): 303-318. 
DEMORTIER, G. \& P. GOETGHEBEUR. 1996. Outil d'évaluation de la qualité du milien physique des cours d'eau-Synthèse. Agence de l'Eau RhinMeuse. 78 pp.

DEPA. 1998. Biological Assessment of Biological Stream Quality. Environmental Guidelines No. 5. Danish Environmental Protection Agency (DEPA), Copenhagen. $39 \mathrm{pp}$.

ELOSEGI, A., L. FLORES \& J. DÍEZ. 2011. The importance of local processess on river habitat characteristics; A Basque stream case study. Limnetica, 30(2): 183-196.

FITZPATRICK, F. A., I. R. WAITE, P. J. D'ARCONTE, M. R. MEADOR, M. A. MAUPIN \& M. E. GURTZ. 1998. Revised methods for characterizing stream habitat in the national water quality assessment program. WRI Report 98-4052. U.S. Geological Survey, Raleigh, N.C. 67 pp.

FREILAND UMWELTCONSULTING. 2001a. $N O ̈-$ MORPH. Strukturkartierung ausgewählter Fließgewässer in Niederösterreich. Endbericht-Teil I: Methodik. Freiland Umweltconsulting.

FREILAND UMWELTCONSULTING. 2001b. $N O ̈-$ MORPH. Strukturkartierung ausgewählter Fließgewässer in Niederösterreich. Endbericht-Teil II: Allgemeines und Ergebnisse. Freiland Umweltconsulting.

FRISSELL, C. A., W. J. LISS, C. E. WARREN \& M. D. HURLEY. 1986. A Hierarchical Framework for Stream Habitat Classification-Viewing Streams in a Watershed Context. Environmental Management, 10(2): 199-214.

GALLI, J. 1996. Final Technical Memorandum: Rapid Stream Assessment Technique (RSAT) Field Methods. Metropolitan Washington Council of Governments, Washington, D.C. $10 \mathrm{pp}$.

GONZÁLEZ DEL TÁNAGO, M. \& D. GARCÍA DE JALÓN. 2011. Riparian Quality Index (RQI): a methodology for characterizing and assessing environmental conditions of riparian zones. Limnetica, 30(2): 235-254.

JOWETT, I. 1997. Instream flow methods: a comparison of approaches. Regulated Rivers: Research \& Management, 13: 115-127.

KAARUP, P. 1999. Indeks for fysisk variation i vandløb. Vand og Jord, 6(4): 136-139.

KAMP, U., W. BINDER \& K. HÖLZL. 2007. River habitat monitoring and assessment in Germany. Environmental Monitoring and Assessment, 127(1): 209-226.
KAUFMANN, P. R., P. LEVINE, E. G. ROBISON, C. SEELIGER \& D. V. PECK. 1999. Quantifying Physical Habitat in Wadeable Streams. EPA/620/R-99/003. U.S. Environmental Protection Agency, Washington, D.C. 149 pp.

KDWP. 2004. Subjective evaluation of aquatic habitats. Kansas Department of Wildlife and Parks, Environmental Services Section, Topeka, KS. 28 pp.

KERN, K., T. FLEISCHHACKER, M. SOMMER \& M. KINDER. 2002. Ecomorphological survey of large rivers: monitoring and assessment of physical habitat conditions and its relevance to biodiversity. Large Rivers, 3: 1-28.

LADSON, A. R., L. J. WHITE, J. A. DOOLAN, B. L. FINLAYSON, B. T. HART, P. S. LAKE \& J. W. TILLEARD. 1999. Development and testing of an Index of Stream Condition for waterway management in Australia. Freshwater Biology, 41: 453-468.

LAWA. 2000. Gewässerstrukturgütebewertung in der Bundesrepublik Deutschlan. Verfahren für kleine und mittelgroße Fließgewässer, Bund/Länder-Arbeitsgemeinschaft Wasser, Berlin.

LAWA. 2002. Gewässerstrukturgütekartierung in der Bundesrepublik Deutschland-Übersichtsverfahren. Empfehlungen Oberirdische Gewässer. Entwurf April 2002. Bund/Länder-Arbeitsgemeinschaft Wasser, Berlin. 28 pp.

LAZORCHAK, J. M., A. T. HERLIHY \& J. GREEN. 1998. Rapid habitat and visual stream assessments. In: EMAP-Surface waters: Field operations and methods for measuring the ecological condition of wadeable streams. USEPA/620/R-94/004F. J.M. Lazorchak, D.J. Klemm, and D.V. Peck (eds.). United States Environmental Protection Agency. Washington, D.C. $211 \mathrm{pp}$.

MADDOCK, I. 1999. The importance of physical habitat assessment for evaluating river health. Freshwater Biology, 41(2): 373-391.

MAGDALENO, F., R. MARTÍNEZ \& V. ROCH. 2010. Índice RFV para la valoración del estado del bosque de ribera. Ingeniería Civil, 157: 85-96.

MATOUŠKOVÁ, M. 2006. Dílči zpráva z grantu GAČR 205/05/P102. Faculty of Science, Charles University in Prague. January 2006. 18 pp.

MATOUŠKOVÁ, M. 2008. Assessment of the river habitat quality within European Water Framework Directive: Application to different catchments in Czechia. Geografie-Sbornik CGS, 113(3): 223236. 
MATOUŠKOVÁ, M. \& M. DVOŘÁK. 2011. Assessment of physical habitat modification in the Bílina River Basin. Limnetica, 30(2): 293-306.

MC GINNITY, P., P. MILLS, W. ROCHE \& M. MÜLLER. 2005. Water Framework Directive: A Desk Study to Determine a Methodology for the Monitoring of the 'Morphological Condition' of Irish Rivers for the Water Framework Directive (2002$W$-DS-9-M1). Environmental Protection Agency, Wexford (Ireland). $237 \mathrm{pp}$.

MOUTON, A. M., J. D. ALCARAZ-HERNANDEZ, B. DE BAETS, P. L. M. GOETHALS \& F. MARTINEZ-CAPEL. 2011. Data-driven fuzzy habitat suitability models for brown trout in Spanish Mediterranean rivers. Environmental Modelling \& Software, 26(5): 615-622.

MPCA. 2002. Physical habitat and water chemistry assessment protocol for wadeable stream monitoring sites. Minnesota Pollution Control Agency, St. Paul, MN. 16 pp.

MUHAR, S., M. SCHWARZ, S. SCHMUTZ \& M. JUNGWIRTH. 2000. Identification of rivers with high and good habitat quality: methodological approach and applications in Austria. Hydrobiologia, 422: 343-358.

MUNNÉ, A., N. PRAT, C. SOLÀ, N. BONADA \& M. RIERADEVALL. 2003. A simple field method for assessing the ecological quality of riparian habitat in rivers and streams: QBR index. Aquatic Conservation: Marine and Freshwater Ecosystems, 13(2): 147-163.

NERI. 1999. National Physical Habitat Index. National Environmental Research Institute (NERI), Roskilde (Denmark).

OHEPA. 2002. Field evaluation manual for Ohio's primary headwater habitat streams. Final Version 1.0. Division of Surface Water, Ohio Environmental Protection Agency, Columbus, Ohio. 66 pp.

OLIVEIRA, S. V. \& R. M. V. CORTES. 2005. A biologically relevant habitat condition index for streams in northern Portugal. Aquatic Conservation: Marine and Freshwater Ecosystems, 15: 189210.

OLLERO, A., L. E. GONZALO, A. IBISATE, V. ACÍN, D. BALLARÍN, E. DÍAZ, S. DOMENECH, M. GIMENO, D. GRANADO, J. HORACIO, D. MORA \& M. SÁNCHEZ. 2011. The IHG index for hydromorphological quality assessment of rivers: updated version. Limnetica, 30(2): 255262.
ORR, H. G., A. R. G. LARGE, M. D. NEWSON \& C. L. WALSH. 2008. A predictive typology for characterising hydromorphology. Geomorphology, 100(1-2): 32-40.

PARDO, I., M. ÁLVAREZ, J. CASAS, J. L. MORENO, S. VIVAS, N. BONADA, J. ALBA-TERCEDOR, P. JÁIMEZ-CUELLAR, G. MOYÁ, N. PRAT, S. ROBLES, M. L. SUÁREZ, M. TORO \& M. R. VIDAL-ABARCA. 2002. El hábitat de los ríos mediterráneos. Diseño de un índice de diversidad de hábitat. Limnetica, 21(3-4): 115-134.

PARSONS, M., M. C. THOMS \& R. H. NORRIS. 2004. Development of a standardised approach to river habitat assessment in Australia. Environmental Monitoring and Assessment, 98: 109-130.

PEDERSEN, M. L., A. SODE, P. KAARUP \& P. BUNDGAARD. 2006. Fysisk kvalitet $i$ vandl $\phi$. Test af to danske indices og udvikling af et nationalt indeks til brug ved overvågning $i$ vandl $\phi$. Danmarks Miljøundersøgelser. Faglig rapport fra DMU 590, Silkeborg, Denmark. 44 pp.

PLAFKIN, J. L., M. T. BARBOUR, K. D. PORTER, S. K. GROSS \& R. M. HUGHES. 1989. Rapid bioassessment protocols for use in streams and rivers-Benthic macroinvertebrates and fish. USEPA 1440/4-89-001. United States Environmental Protection Agency. Washington, D.C. 35 pp.

PLATTS, W. S., W. F. MEGAHAN \& G. W. MINSHALL. 1983. Methods for evaluating stream, riparian, and biotic conditions. U.S. Department of Agriculture, Forest Service, Intermountain Forest and Range Experiment Station. Ogden, UT. 70 pp. PRICHARD, D., H. BARRETT, J. CAGNEY, R. CLARK, J. FOGG, K. GEBHARDT, P. L. HANSEN, B. MITCHELL \& D. TIPPY. 1998. Riparian area management: Process for assessing proper functioning condition. Bureau of Land Management, Denver, CO. 58 pp.

RANKIN, E. T. 2006. Methods for assessing habitat in flowing waters: Using the qualitative habitat evaluation index. Revised by Midwest Biodiversity Institute for Ohio Environmental Protection Agency, Ecological Assessment Division. Groveport, OH. 26 pp.

RAVEN, P. J., P. FOX, M. EVERARD, N. T. H. HOLMES \& F. H. DAWSON. 1997. River Habitat Survey: a new system for classifying rivers according to their habitat quality. In: Freshwater quality: Defining the indefinable? P. J. Boon \& D. L. Howell (eds.): 215-234. The Stationery Office, Edinburgh. 
RAVEN, P. J., N. HOLMES, J. PÁDUA, J. FERREIRA, S. HUGHES, L. BAKER, L. TAYLOR \& K. SEAGER. 2009. River Habitat Survey in Southern Portugal: Results from 2009. Environment Agency \& Centre for Ecology and Hydrology. Bristol and Wallingford, UK. 29 pp.

RAVEN, P. J., N. T. H. HOLMES, P. CHARRIER, F. H. DAWSON, M. NAURA \& P. J. BOON. 2002. Towards a harmonized approach for hydromorphological assessment of rivers in Europe: a qualitative comparison of three methods. Aquatic Conservation: Marine and Freshwater Ecosystems, 12: 405424.

RAVEN, P. J., N. T. H. HOLMES, F. H. DAWSON \& M. EVERARD. 1998. Quality assessment using River Habitat Survey data. Aquatic Conservation: Marine and Freshwater Ecosystems, 8: 477-499.

RAVEN, P. J., N. T. H. HOLMES, I. P. VAUGHAN, F. H. DAWSON \& P. SCARLETT. 2010. Benchmarking habitat quality: observations using River Habitat Survey on near-natural streams and rivers in northern and western Europe. Aquatic Conservation: Marine and Freshwater Ecosystems, 20(1): S13-S30.

ROSGEN, D. L. 1994. A Classification of Natural Rivers. Catena, 22(3): 169-199.

ROSGEN, D. L. 1996. Applied river morphology. Wildland Hydrology. Pagosa Springs, CO. 400 pp.

ROWNTREE, K. M. \& R. A. WADESON. 1998. A geomorphological framework for the assessment of instream flow requirements. Aquatic Ecosystem Health and Management, 1: 125-141.

SCHNEIDERS, A., E. VERHAERT, G. D. BLUST, C. WILS, L. BERVOETS \& R. F. VERHEYEN. 1993. Towards an ecological assessment of watercourses. Journal of Aquatic Ecosystem Health, 2: $29-38$.

SILIGARDI, M., F. AVOLIO, G. BALDACCINI, S. BERNABEI, M. S. BUCCI, C. CAPPELLETTI, E. CHIERICI, F. CIUTTI, B. FLORIS, A. FRANCESCHINI, L. MANCINI, M. R. MINCIARDI, C. MONAUNI, P. NEGRI, G. PINESCHI, S. POZZI, G. L. ROSSI, G. SANSONI, R. SPAGGIARI, C. TAMBURRO \& M. ZANETTI. 2007. IFF 2007 Indice di Funzionalità Fluviale. Nuova versione del metodo revisionata e aggiornata. Agenzia per la Protezione dell'Ambiente e per i Servizi Tecnici (APAT). Roma (Italy). 325 pp.

SILIGARDI, M., S. BERNABEI, C. CAPPELLETTI, E. CHIERICI, F. CIUTTI, F. EGADDI, A. FRANCESCHINI, B. MAIOLINI, L. MANCINI,
M. R. MINCIARDI, C. MONAUNI, G. L. ROSSI, G. SANSONI, R. SPAGGIARI \& M. ZANETTI. 2000. IFF Indice di Funzionalità FluvialeManuale di applicazione. Agenzia Nazionale per la Protezione dell' Ambiente (ANPA). Roma (Italy). 223 pp.

ŠÍPEK, V., M. MATOUŠKOVÁ \& M. DVOŘÁK. 2009. Comparative analysis of selected hydromorphological assessment methods. Environmental Monitoring and Assessment, 10: 1-11.

SKRIVER, J., T. RIIS, J. CARL, A. BAATTRUPPEDERSEN, N. FRIBERG, M. E. ERNST, S. B. FRANDSEN, A. SODE \& P. WIBERGLARSEN. 2003. Biologisk overvågning $i$ vandløb 1998-2003. Miljø- og Energiministeriet Danmarks Miljøundersøgelser. Silkeborg, Denmark. 41 pp.

SMITH, R. L. 1990. Ecology and field biology, Harper Collins, New York. 999 pp.

SNELDER, T. H., N. LAMOUROUX \& H. PELLA. 2011. Statistical modeling of large scale patterns in river sediment grain-size. Geomorphology, 127: 189-197.

SOLÀ, C., M. ORDEIX, Q. POU-ROVIRA, N. SELLARÈS, A. QUERALT, M. BARDINA, A. CASAMITJANA \& A. MUNNÉ. 2011. Analysing river connectivity for hydromorphological improvement in mediterranean rivers. The ICF index and its application in catalan rivers. Limnetica, 30(2): 273-292.

SPIEGLER, A., G. IMHOFF, B. PELIKAN \& M. KATZMANN. 1989. Strukturökologische. Methode zur Bestandsaufnahme und Bewertung von Fließgewässern. Planungen und Untersuchungen. Bundesministerium für Land- und Forstwirtschaft, Wasserwirtschaftskataster, Wien.

STARR, R. R. \& T. MCCANDLESS. 2001. Stream and riparian habitats rapid assessment protocol. Chesapeake Bay Field Office, U.S. Fish and Wildlife Service, Annapolis, MD. 28 pp.

TICKNER, D., P. D. ARMITAGE, M. A. BICKERTON \& K. A. HALL. 2000. Assessing stream quality using information on mesohabitat distribution and character. Aquatic Conservation: Marine and Freshwater Ecosystems, 10: 179-196.

USEPA. 1997. Volunteer Stream Monitoring: A Methods Manual. EPA 841-B-97-003. U.S. Environmental Protection Agency, Office of Water, Washington, DC. 227 pp.

USEPA. 2004. Wadeable stream assessment: Field operations manual. EPA841-B-04-004. U.S. Environmental Protection Agency, Office of Water and 
Office of Research and Development, Washington, DC. 191 pp.

VAUGHAN, I. P., M. DIAMOND, A. M. GURNELL, K. A. HALL, A. JENKINS, N. J. MILNER, L. A. NAYLOR, D. A. SEAR, G. WOODWARD \& S. J. ORMEROD. 2009. Integrating ecology with hydromorphology: a priority for river science and management. Aquatic Conservation: Marine and Freshwater Ecosystems, 19(1): 113-125.

VTANR. 2004. Vermont stream geomorphic assessment protocol handbooks. Vermont Agency of Natural Resources, Waterbury, VT. 60 pp.

WEIß, A., M. MATOUSKOVA \& J. MATSCHUL-
LAT. 2008. Hydromorphological assessment within the EU-Water Framework Directive-transboundary cooperation and application to different water basins. Hydrobiologia, 603(1): 53-72.

WERTH, W. 1987. Ökomorphologische Gewässerbewertung in Oberösterreich (Gewässerzustandkartierungen). Eco-morphological classification of channels in Upper Austria. In: Österreichische Wasserwirtschaft, 39: 122-128.

WILHELM, J. G. O., J. D. ALLAN, K. J. WESSELL, R. W. MERRIT \& K. W. CUMMINS. 2005. Habitat assessment of non-wadeable rivers in Michigan. Environmental Management, 36(4): 592-609. 
Appendix I. Physical river habitat characterisation and assessment methods considered in this paper, with codes and references.

\begin{tabular}{|c|c|c|c|}
\hline \multicolumn{4}{|c|}{ Methods from European Countries } \\
\hline $\begin{array}{l}\text { Physical Habitat Assessment } \\
\text { Method }\end{array}$ & Code & Original references & References Analysed \\
\hline $\begin{array}{l}\text { Index for the assessment of fluvial } \\
\text { habitat in Mediterranean rivers (IHF) }\end{array}$ & IHF & Pardo et al., 2002 & Original reference \\
\hline Hydro Geomorphologic Index (IHG) & IHG & Ollero et al., 2011 & Original references \\
\hline Riparian Quality Index (RQI) & RQI & $\begin{array}{l}\text { González del Tánago \& García de } \\
\text { Jalón, } 2011\end{array}$ & Original references \\
\hline Qualitat del Bosc de Ribera (QBR) & QBR & Munné et al., 2003 & Original reference \\
\hline Riparian Forest EValuation & RFV & Magdaleno et al., 2010 & Original reference \\
\hline $\begin{array}{l}\text { Protocolo para la valoración de la } \\
\text { calidad hidromorfológica de los ríos } \\
\text { (protocolo HIDRI) }\end{array}$ & HIDRI & ACA, 2006 & Original reference \\
\hline Habitat Condition Index (HCI) & $\mathrm{HCI}$ & Oliveira \& Cortes, 2005 & Original reference \\
\hline River Habitat Survey (RHS) & RHS & $\begin{array}{l}\text { Raven et al., 1997; Raven et al., } \\
1998\end{array}$ & Original references \\
\hline Mesohabitat Approach & MesoH & Tickner et al., 2000 & Original reference \\
\hline Urban River Survey (URS) & URS & Davenport et al., 2004 & Original reference \\
\hline QUALPHY & Qualphy & Demortier \& Goetghebeur, 1996 & Mc Ginnity et al., 2005 \\
\hline SEQ-Physique & SEQ-P & $\begin{array}{l}\text { Agences de l'Eau \& Ministére de } \\
\text { l'Environnement, } 1998\end{array}$ & $\begin{array}{l}\text { Raven et al., 2002; Mc Ginnity et al., } \\
2005\end{array}$ \\
\hline $\begin{array}{l}\text { Buffer Strip Index and Wild State } \\
\text { Index }\end{array}$ & BSI\&WSI & Braioni et al., 2001 & Mc Ginnity et al., 2005 \\
\hline Index of Fluvial Functioning (IFF) & IFF & $\begin{array}{l}\text { Siligardi et al., 2000; Siligardi et al., } \\
2007\end{array}$ & Original reference \\
\hline $\begin{array}{l}\text { Eco-morphological classification of } \\
\text { channels according to WERTH }\end{array}$ & Werth & Werth, 1987 & Mc Ginnity et al., 2005 \\
\hline $\begin{array}{l}\text { Ecological method for inventory and } \\
\text { assessment of watercourse structures }\end{array}$ & WatercSt & Spiegler et al., 1989 & Mc Ginnity et al., 2005 \\
\hline $\begin{array}{l}\text { River structures: } \\
\text { Recording-Assessing-Representing }\end{array}$ & RSR & Buhmann \& Hutter, 1996 & Mc Ginnity et al., 2005 \\
\hline $\begin{array}{l}\text { Assessment of river stretches with } \\
\text { high or good habitat quality }\end{array}$ & AssRivSt & Muhar et al., 2000 & Original reference \\
\hline River's Atlas Tyrol & RATyrol & ADTL, 1996a; ADTL, 1996b & Mc Ginnity et al., 2005 \\
\hline NÖMORPH & Nömorph & $\begin{array}{l}\text { Freiland Umweltconsulting, 2001a; } \\
\text { Freiland Umweltconsulting, 2001b }\end{array}$ & Mc Ginnity et al., 2005 \\
\hline Stream Habitat Survey (LAWA-FS) & LAWA-FS & LAWA, 2000 & $\begin{array}{l}\text { Kamp et al., 2007; Raven } \text { et al., } \\
\text { 2002; Śípek et al., 2009; Weiß et al., } \\
2008\end{array}$ \\
\hline LAWA-OS & LAWA-OS & LAWA, 2002 & $\begin{array}{l}\text { Kamp et al., 2007; Šípek et al., 2009; } \\
\text { Weiß et al., } 2008\end{array}$ \\
\hline $\begin{array}{l}\text { Ecomorphological Survey of Large } \\
\text { Rivers }\end{array}$ & ESLR & Kern et al.,2002 & Original reference \\
\hline $\begin{array}{l}\text { Quick assessment of the overall } \\
\text { physical quality of streams as part of } \\
\text { the DSFI sampling }\end{array}$ & DSFI & DEPA, 1998 & Mc Ginnity et al., 2005 \\
\hline Aarhus Index & Aarhus & Kaarup, 1999 & Mc Ginnity et al., 2005 \\
\hline National Physical Habitat Index & NPHI & NERI, 1999; Pedersen et al., 2006 & Mc Ginnity et al., 2005 \\
\hline $\begin{array}{l}\text { Characterisation of the physical } \\
\text { stream conditions within the } \\
\text { Extended Biology Program }\end{array}$ & PhysSC & Skriver et al., 2003 & Original reference \\
\hline $\begin{array}{l}\text { Structural Evaluation of } \\
\text { Watercourses }\end{array}$ & SEvalW & Schneiders et al., 1993 & Mc Ginnity et al., 2005 \\
\hline EcoRivHab & EcoRivHab & $\begin{array}{l}\text { Matoušková, 2006; Matoušková, } \\
2008\end{array}$ & Original references \\
\hline
\end{tabular}


Appendix I (cont.)

\begin{tabular}{|c|c|c|c|}
\hline \multicolumn{4}{|c|}{ Methods from other Non-European Countries } \\
\hline $\begin{array}{l}\text { Physical Habitat Assessment } \\
\text { Method }\end{array}$ & Code & Original references & References Analysed \\
\hline State of the Rivers Survey & SRS & Anderson, 1993 & Mc Ginnity et al., 2005 \\
\hline Geomorphic River Styles & GRS & Brierly et al., 1996 & Original reference \\
\hline Index of Stream Condition & ISC & Ladson et al., 1999 & Original reference \\
\hline River Styles & $\mathrm{RS}$ & Brierly \& Fryirs, 2000 & Original reference \\
\hline Habitat Predictive Modelling & HPM & Davies et al., 2000 & Original reference \\
\hline $\begin{array}{l}\text { AusRivAS Physical Assessment } \\
\text { Protocol }\end{array}$ & AusRivAs & Parsons et al., 2004 & Original reference \\
\hline $\begin{array}{l}\text { River Health Programme Index } \\
\text { (Geomorphological Index) }\end{array}$ & RHPI & Rowntree \& Wadeson, 1998 & Mc Ginnity et al., 2005 \\
\hline $\begin{array}{l}\text { Methods for Evaluating Streams } \\
\text { Conditions }\end{array}$ & MESC & Platts et al., 1983 & Original reference \\
\hline HABSCORE (RBP) & $\mathrm{RBP}$ & $\begin{array}{l}\text { Plafkin et al., 1989; Barbour et al., } \\
1999\end{array}$ & Original references \\
\hline Applied River Morphology-Method & ARM & Rosgen, 1996 & Original reference \\
\hline $\begin{array}{l}\text { Rapid Stream Assessment Technique } \\
\text { Field Methods - RSAT }\end{array}$ & RSAT & Galli, 1996 & Original reference \\
\hline $\begin{array}{l}\text { Volunteer Stream Monitoring } \\
\text { Method }\end{array}$ & VSMM & USEPA, 1997 & Mc Ginnity et al., 2005 \\
\hline $\begin{array}{l}\text { Rapid Habitat and Visual Stream } \\
\text { Assessments-Environmental } \\
\text { Monitoring and Assessment Program }\end{array}$ & RHVSH & Lazorchack et al., 1998 & $\begin{array}{l}\text { Ecological Assessment Methods } \\
\text { Database (www.nbii.gov) }\end{array}$ \\
\hline $\begin{array}{l}\text { Methods for Characterizing Stream } \\
\text { Habitat-National Water-Quality } \\
\text { Assessment }\end{array}$ & NAWQA & Fitzpatrick et al., 1998 & Original reference \\
\hline $\begin{array}{l}\text { Physical Habitat } \\
\text { Characterization-Environmental } \\
\text { Monitoring and Assessment Program }\end{array}$ & PHC-EMAP & Kaufmann et al., 1999 & Mc Ginnity et al., 2005 \\
\hline Proper Functioning Condition & PFC & Prichard et al.,1998 & Original reference \\
\hline $\begin{array}{l}\text { Stream and Riparian Habitats Rapid } \\
\text { Assessment Protocol }\end{array}$ & SRHRAP & Starr \& McCandless, 2001 & $\begin{array}{l}\text { Ecological Assessment Methods } \\
\text { Database (www.nbii.gov) }\end{array}$ \\
\hline $\begin{array}{l}\text { Minnesota Habitat and Water } \\
\text { Chemistry Protocol }\end{array}$ & MinHWCP & MPCA, 2002 & Original reference \\
\hline $\begin{array}{l}\text { Montana Natural Heritage Wetland } \\
\text { Assessment-GIS based }\end{array}$ & MNHWA & Crowe \& Kudray, 2003 & Original reference \\
\hline $\begin{array}{l}\text { Subjective Evaluation of Aquatic } \\
\text { Habitats }\end{array}$ & SEvalAH & KDWP, 2004 & Original reference \\
\hline $\begin{array}{l}\text { Wadeable Stream Assessment Field } \\
\text { Ops }\end{array}$ & WSAss & USEPA, 2004 & Original reference \\
\hline $\begin{array}{l}\text { Vermont Stream Geomorphic } \\
\text { Assessment Protocol Handbooks }\end{array}$ & VSGA & VTANR, 2004 & Original reference \\
\hline $\begin{array}{l}\text { Beneficial Use Reconnaissance } \\
\text { Program (BURP) Stream Protocol }\end{array}$ & BURP & BURP TAC, 2004 & Original reference \\
\hline Non Wadeable Habitat Index & NWHI & Wilhelm et al., 2005 & Original reference \\
\hline $\begin{array}{l}\text { OHEPA Primary Headwater Habitat } \\
\text { Stream Evaluation }\end{array}$ & PHWH & OHEPA, 2002 & Original reference \\
\hline Qualitative Habitat Evaluation Index & QHEI & Rankin, 2006 & Original reference \\
\hline
\end{tabular}


Appendix II. River habitat characteristics included in methods applied to European, Australian and North American rivers.

Table 1. River habitat characteristics described in the CEN standard (2002) that are included in river habitat assessment methods developed for application to European rivers. Methods are coded as in Appendix I. "Y" (yes) indicates that the method includes the characteristic, "N" (no) indicates that it does not, "P" (potential) indicates that the characteristic can be obtained indirectly from other information gathered by the method and " $i$ ?"indicates that insufficient information is available to assign the method to one of the other three categories. Características del hábitat físico descritas en el estándar CEN (2002) que están incluidas en los métodos de evaluación del hábitat físico desarrollados para su aplicación en ríos europeos (los métodos están abreviados según el Anexo I). "Y" (sí) aparece cuando el método incluye la característica, " $N$ " cuando no, " $P$ " (potencial) cuando la característica puede obtenerse indirectamente a partir de otra información recogida por el método y " ¿?" cuando no se encontró dicha información durante la revisión.

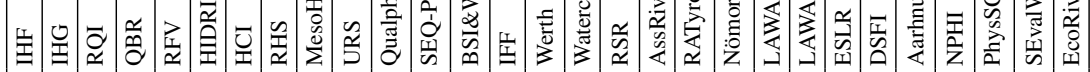

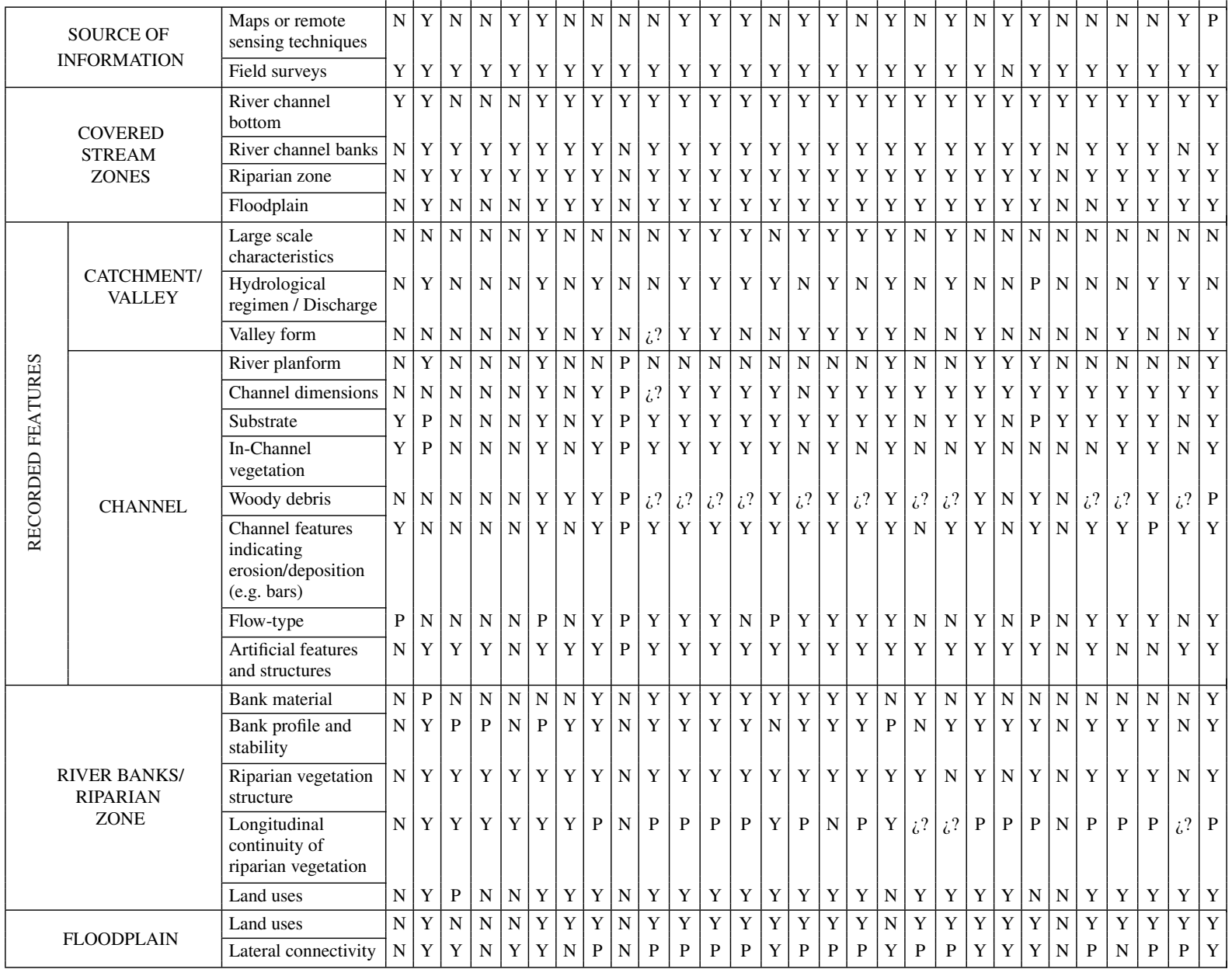


Appendix II (cont.)

Table 2. River habitat characteristics described in the CEN standard (2002) that are included in river habitat assessment methods developed for application in Australian and North American rivers. Methods are coded as in Appendix I, and the entries in the table are as described for Table 1. Características del hábitat físico descritas en el estándar CEN (2002) que están incluidas en los métodos de evaluación del hábitat físico desarrollados para su aplicación en ríos australianos y norteamericanos (los métodos están abreviados según el Anexo I). " $Y$ " ( sí) aparece cuando el método incluye la característica, " $N$ " cuando no, " $P$ " (potencial) cuando la característica puede obtenerse indirectamente a partir de otra información recogida por el método y "¿?” cuando no se encontró dicha información durante la revisión.

\begin{tabular}{|c|c|c|c|c|c|c|c|c|c|c|c|c|c|c|c|c|c|c|c|c|c|c|c|c|c|c|c|c|}
\hline & & & & & & & & & & & & & & & & & & & & & & & & & & & & \\
\hline & & & $\frac{n}{n}$ & $\begin{array}{l}n \\
\frac{n}{0}\end{array}$ & 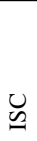 & $\approx$ & $\sum_{\text {主 }}$ & 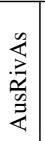 & $\stackrel{\overrightarrow{\underline{z}}}{\underline{\underline{z}}}$ & 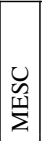 & $\frac{\vec{m}}{\alpha}$ & 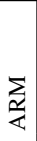 & 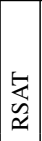 & $\sum_{\substack{\infty \\
>}}$ & $\begin{array}{l}\frac{1}{2} \\
2 \\
2 \\
2 \\
\end{array}$ & d & 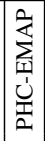 & 诘 & 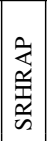 & 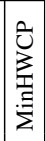 & 离 & 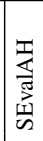 & 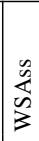 & $\begin{array}{l}\nwarrow \\
0 \\
\infty \\
>\end{array}$ & 芯 & 产 & $\sum_{2}^{M}$ & 武 \\
\hline \multirow{2}{*}{\multicolumn{2}{|c|}{$\begin{array}{l}\text { SOURCE OF } \\
\text { INFORMATION }\end{array}$}} & $\begin{array}{l}\text { Maps or remote } \\
\text { sensing techniques }\end{array}$ & $\mathrm{N}$ & $\bar{Y}$ & $\mathrm{Y}$ & $\mathrm{Y}$ & $\mathrm{N}$ & $\mathrm{Y}$ & \begin{tabular}{|l|}
$\mathrm{Y}$ \\
\end{tabular} & $\mathrm{Y}$ & $\mathrm{N}$ & $\mathrm{N}$ & $\mathrm{N}$ & $\mathrm{N}$ & $\mathrm{N}$ & $\mathrm{Y}$ & $\mathrm{N}$ & $\mathrm{P}$ & $\mathrm{N}$ & $\mathrm{N}$ & $\mathrm{Y}$ & $\mathrm{N}$ & $\mathrm{N}$ & $\mathrm{Y}$ & $\mathrm{Y}$ & $\mathrm{N}$ & $\mathrm{N}$ & $\mathrm{N}$ \\
\hline & & Field surveys & $\mathrm{Y}$ & $\mathrm{Y}$ & $\mathrm{Y}$ & Y & Y & $\mathrm{Y}$ & $\mathrm{Y}$ & $\mathrm{Y}$ & $\mathrm{Y}$ & $\mathrm{Y}$ & $\mathrm{Y}$ & $\mathrm{Y}$ & $\mathrm{Y}$ & Y & $\mathrm{Y}$ & $\mathrm{Y}$ & $\mathrm{Y}$ & $\mathrm{Y}$ & $\mathrm{N}$ & $\mathrm{Y}$ & Y & Y & Y & $\mathrm{Y}$ & $\mathrm{Y}$ & Y \\
\hline \multirow{4}{*}{\multicolumn{2}{|c|}{$\begin{array}{l}\text { COVERED } \\
\text { STREAM } \\
\text { ZONES }\end{array}$}} & $\begin{array}{l}\text { River channel } \\
\text { bottom }\end{array}$ & $\mathrm{Y}$ & $\mathrm{Y}$ & $\mathrm{Y}$ & $\mathrm{Y}$ & $\mathrm{Y}$ & $\mathrm{Y}$ & $\mathrm{Y}$ & $\mathrm{Y}$ & $\mathrm{Y}$ & $\mathrm{Y}$ & $\mathrm{Y}$ & $\mathrm{Y}$ & $\mathrm{Y}$ & $\mathrm{Y}$ & $\mathrm{Y}$ & $\mathrm{Y}$ & $\mathrm{Y}$ & $\mathrm{Y}$ & $\mathrm{Y}$ & $\mathrm{Y}$ & $\mathrm{Y}$ & $\mathrm{Y}$ & $\mathrm{Y}$ & $\mathrm{Y}$ & $\mathrm{Y}$ & $\mathrm{Y}$ \\
\hline & & River channel banks & $\mathrm{Y}$ & $\mathrm{N}$ & $\mathrm{Y}$ & $\mathrm{N}$ & Y & $\mathrm{Y}$ & $\mathrm{Y}$ & $\mathrm{Y}$ & $\mathrm{Y}$ & $\mathrm{Y}$ & $\mathrm{Y}$ & $\mathrm{Y}$ & $\mathrm{Y}$ & $\mathrm{Y}$ & $\mathrm{Y}$ & $\mathrm{Y}$ & $\mathrm{Y}$ & $\mathrm{Y}$ & $\mathrm{Y}$ & $\mathrm{Y}$ & Y & Y & Y & Y & $\mathrm{Y}$ & Y \\
\hline & & Riparian zone & $\mathrm{Y}$ & $\mathrm{Y}$ & $\mathrm{Y}$ & $\mathrm{Y}$ & $\mathrm{Y}$ & $\mathrm{Y}$ & $\mathrm{Y}$ & $\mathrm{Y}$ & $\mathrm{Y}$ & $\mathrm{Y}$ & $\mathrm{Y}$ & $\mathrm{Y}$ & $\mathrm{Y}$ & $\mathrm{Y}$ & $\mathrm{Y}$ & $\mathrm{Y}$ & $\mathrm{Y}$ & $\mathrm{Y}$ & $\mathrm{Y}$ & $\mathrm{Y}$ & $\mathrm{Y}$ & $\mathrm{Y}$ & $\mathrm{N}$ & $\mathrm{Y}$ & $\mathrm{Y}$ & $\mathrm{Y}$ \\
\hline & & Floodplain & $\mathrm{Y}$ & Y & $\mathrm{N}$ & Y & Y & $\mathrm{Y}$ & $\mathrm{Y}$ & $\mathrm{Y}$ & $\mathrm{N}$ & $\mathrm{Y}$ & $\mathrm{N}$ & $\mathrm{Y}$ & $\mathrm{Y}$ & $\mathrm{Y}$ & $\mathrm{N}$ & $\mathrm{Y}$ & $\mathrm{N}$ & $\mathrm{N}$ & $\mathrm{Y}$ & $\mathrm{Y}$ & $\mathrm{N}$ & $\mathrm{Y}$ & Y & $\mathrm{N}$ & $\mathrm{Y}$ & Y \\
\hline \multirow{11}{*}{ 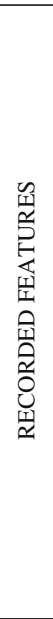 } & \multirow{3}{*}{$\begin{array}{l}\text { CATCHMENT/ } \\
\text { VALLEY }\end{array}$} & $\begin{array}{l}\text { Large scale } \\
\text { characteristics }\end{array}$ & $\mathrm{Y}$ & $\mathrm{Y}$ & $\mathrm{Y}$ & $\mathrm{Y}$ & $\mathrm{Y}$ & $\mathrm{Y}$ & $\mathrm{N}$ & $\mathrm{Y}$ & $\mathrm{N}$ & $\mathrm{Y}$ & $\mathrm{N}$ & $\mathrm{N}$ & $\mathrm{N}$ & $\mathrm{Y}$ & $\mathrm{N}$ & $\mathrm{N}$ & i? & $\mathrm{N}$ & $\mathrm{Y}$ & $\mathrm{N}$ & $\mathrm{N}$ & $\mathrm{Y}$ & $\mathrm{N}$ & $\mathrm{N}$ & $\mathrm{Y}$ & $\mathrm{N}$ \\
\hline & & $\begin{array}{l}\text { Hydrological } \\
\text { regimen / Discharge }\end{array}$ & $\mathrm{Y}$ & Y & $\mathrm{Y}$ & Y & Y & $\mathrm{Y}$ & $\mathrm{N}$ & $\mathrm{Y}$ & $\mathrm{N}$ & $\mathrm{Y}$ & $\mathrm{N}$ & $\mathrm{N}$ & $\mathrm{N}$ & $\mathrm{Y}$ & $\mathrm{Y}$ & $\mathrm{N}$ & i? & $\mathrm{N}$ & $\mathrm{N}$ & $\mathrm{N}$ & $\mathrm{Y}$ & $\mathrm{N}$ & $\mathrm{N}$ & $\mathrm{N}$ & $\mathrm{P}$ & $\mathrm{N}$ \\
\hline & & Valley form & $\mathrm{N}$ & $\mathrm{Y}$ & $\mathrm{N}$ & $\mathrm{Y}$ & $\mathrm{Y}$ & $\mathrm{Y}$ & $\mathrm{Y}$ & $\mathrm{N}$ & $\mathrm{N}$ & $\mathrm{Y}$ & $\mathrm{N}$ & $\mathrm{N}$ & $\mathrm{N}$ & $\mathrm{Y}$ & $\mathrm{N}$ & $\mathrm{N}$ & $i ?$ & $\mathrm{~N}$ & $\mathrm{~N}$ & $\mathrm{~N}$ & $\mathrm{Y}$ & $\mathrm{Y}$ & $\mathrm{N}$ & $\mathrm{N}$ & $\mathrm{N}$ & $\mathrm{N}$ \\
\hline & \multirow{8}{*}{ CHANNEL } & River planform & $\mathrm{Y}$ & $\mathrm{Y}$ & $\mathrm{N}$ & $\mathrm{Y}$ & $\mathrm{N}$ & $\mathrm{Y}$ & \begin{tabular}{|l|}
$\mathrm{Y}$ \\
\end{tabular} & $\mathrm{P}$ & $P$ & $\mathrm{Y}$ & $\mathrm{N}$ & $\mathrm{N}$ & $\mathrm{P}$ & $\mathrm{Y}$ & $\mathrm{N}$ & $\mathrm{Y}$ & i? & $\mathrm{N}$ & $\mathrm{N}$ & $\mathrm{Y}$ & $\mathrm{Y}$ & $\mathrm{Y}$ & $\mathrm{P}$ & $\mathrm{N}$ & $\mathrm{Y}$ & $\mathrm{P}$ \\
\hline & & Channel dimensions & $\mathrm{Y}$ & $\mathrm{Y}$ & $\mathrm{N}$ & $\mathrm{Y}$ & $\mathrm{Y}$ & $\mathrm{Y}$ & $\mathrm{Y}$ & $\mathrm{Y}$ & $\mathrm{N}$ & $\mathrm{Y}$ & $\mathrm{N}$ & $\mathrm{N}$ & $\mathrm{N}$ & $\mathrm{Y}$ & $\mathrm{Y}$ & $\mathrm{Y}$ & $i ?$ & $\mathrm{Y}$ & $\mathrm{N}$ & $\mathrm{N}$ & $\mathrm{Y}$ & $\mathrm{Y}$ & $\mathrm{Y}$ & $\mathrm{N}$ & $\mathrm{Y}$ & $\mathrm{Y}$ \\
\hline & & Substrate & $\mathrm{Y}$ & $\mathrm{Y}$ & $\mathrm{N}$ & $\mathrm{Y}$ & $\mathrm{Y}$ & $\mathrm{Y}$ & $\mathrm{Y}$ & $\mathrm{Y}$ & $\mathrm{N}$ & $\mathrm{Y}$ & $\mathrm{P}$ & $\mathrm{Y}$ & $\mathrm{Y}$ & $\mathrm{Y}$ & $\mathrm{Y}$ & $\mathrm{N}$ & $i ?$ & $\mathrm{Y}$ & $\mathrm{N}$ & $\mathrm{Y}$ & $\mathrm{Y}$ & $\mathrm{Y}$ & $\mathrm{Y}$ & $\mathrm{Y}$ & $\mathrm{Y}$ & Y \\
\hline & & $\begin{array}{l}\text { In-Channel } \\
\text { vegetation }\end{array}$ & $\mathrm{Y}$ & $\mathrm{N}$ & $\mathrm{N}$ & $\mathrm{N}$ & $\mathrm{N}$ & $\mathrm{Y}$ & $\mathrm{Y}$ & $\mathrm{N}$ & $\mathrm{Y}$ & $\mathrm{N}$ & $\mathrm{N}$ & $\mathrm{Y}$ & $\mathrm{N}$ & $\mathrm{Y}$ & $\mathrm{N}$ & $\mathrm{N}$ & ¿? & $\mathrm{Y}$ & $\mathrm{N}$ & $\mathrm{N}$ & $\mathrm{Y}$ & $\mathrm{Y}$ & Y & $\mathrm{Y}$ & $\mathrm{N}$ & $\mathrm{Y}$ \\
\hline & & Woody debris & $\mathrm{Y}$ & $\mathrm{N}$ & $\mathrm{N}$ & Y & $\mathrm{N}$ & ¿? & $\mathrm{N}$ & $\mathrm{Y}$ & $\mathrm{Y}$ & $\mathrm{N}$ & $\mathrm{N}$ & $\mathrm{Y}$ & $\mathrm{P}$ & $\mathrm{Y}$ & $\mathrm{Y}$ & $P$ & $i ?$ & $\mathrm{Y}$ & $\mathrm{N}$ & Y & Y & $\mathrm{Y}$ & Y & Y & $\mathrm{Y}$ & Y \\
\hline & & $\begin{array}{l}\text { Channel features } \\
\text { indicating } \\
\text { erosion/deposition } \\
\text { (e.g. bars) }\end{array}$ & $\mathrm{Y}$ & $\mathrm{N}$ & ¿? & $\mathrm{P}$ & $\mathrm{N}$ & $\mathrm{Y}$ & $\mathrm{Y}$ & $\mathrm{Y}$ & $\mathrm{N}$ & $\mathrm{N}$ & $\mathrm{P}$ & $\mathrm{Y}$ & $\mathrm{N}$ & $\mathrm{Y}$ & $\mathrm{N}$ & $\mathrm{Y}$ & i? & $\mathrm{N}$ & $\mathrm{N}$ & $\mathrm{Y}$ & Y & $Y$ & $\mathrm{~N}$ & $\mathrm{~N}$ & $\mathrm{~N}$ & $\mathrm{Y}$ \\
\hline & & Flow-type & \multirow{2}{*}{$\begin{array}{l}\mathrm{P} \\
\mathrm{Y}\end{array}$} & Y & $\mathrm{N}$ & $\mathrm{P}$ & $\mathrm{N}$ & $\mathrm{Y}$ & $\mathrm{Y}$ & $\mathrm{Y}$ & $\mathrm{P}$ & $\mathrm{N}$ & $\mathrm{P}$ & $\mathrm{Y}$ & $\mathrm{P}$ & $\mathrm{P}$ & $\mathrm{N}$ & $\mathrm{N}$ & ¿? & $\mathrm{P}$ & $\mathrm{P}$ & $\mathrm{P}$ & $\mathrm{P}$ & $\mathrm{P}$ & $\mathrm{P}$ & $\mathrm{N}$ & $\mathrm{N}$ & $\mathrm{Y}$ \\
\hline & & $\begin{array}{l}\text { Artificial features } \\
\text { and structures }\end{array}$ & & $\mathrm{N}$ & $\mathrm{Y}$ & $\mathrm{N}$ & $\mathrm{N}$ & $\mathrm{Y}$ & $\mathrm{N}$ & $\mathrm{N}$ & $\mathrm{Y}$ & $\mathrm{Y}$ & $\mathrm{N}$ & $\mathrm{Y}$ & $\mathrm{Y}$ & $\mathrm{Y}$ & $\mathrm{Y}$ & $\mathrm{Y}$ & i? & $\mathrm{Y}$ & $\mathrm{Y}$ & $\mathrm{Y}$ & $\mathrm{Y}$ & $\mathrm{Y}$ & $\mathrm{N}$ & $\mathrm{N}$ & $\mathrm{Y}$ & $\mathrm{Y}$ \\
\hline \multirow{4}{*}{\multicolumn{2}{|c|}{$\begin{array}{l}\text { RIVER BANKS/ } \\
\text { RIPARIAN } \\
\text { ZONE }\end{array}$}} & Bank material & $\mathrm{N}$ & $\mathrm{N}$ & $\mathrm{N}$ & $\mathrm{N}$ & $\mathrm{Y}$ & $\mathrm{Y}$ & $\mathrm{Y}$ & $\mathrm{N}$ & $\mathrm{N}$ & $\mathrm{Y}$ & $\mathrm{N}$ & $\mathrm{N}$ & $\mathrm{N}$ & $\mathrm{Y}$ & $\mathrm{N}$ & $\mathrm{N}$ & ¿? & $\mathrm{N}$ & $\mathrm{N}$ & $\mathrm{N}$ & $Y$ & $\mathrm{Y}$ & $\mathrm{N}$ & $\mathrm{N}$ & $\mathrm{N}$ & $\mathrm{N}$ \\
\hline & & $\begin{array}{l}\text { Bank profile and } \\
\text { stability }\end{array}$ & $\mathrm{Y}$ & $\mathrm{N}$ & $\mathrm{Y}$ & $\mathrm{N}$ & $\mathrm{Y}$ & $\mathrm{Y}$ & $\mathrm{Y}$ & $\mathrm{Y}$ & $\mathrm{Y}$ & $\mathrm{Y}$ & $\mathrm{Y}$ & $\mathrm{Y}$ & $\mathrm{Y}$ & $\mathrm{Y}$ & $\mathrm{Y}$ & $\mathrm{Y}$ & Y & $\mathrm{Y}$ & $\mathrm{N}$ & $\mathrm{Y}$ & $\mathrm{Y}$ & $\mathrm{Y}$ & Y & $\mathrm{Y}$ & $\mathrm{N}$ & $\mathrm{Y}$ \\
\hline & & $\begin{array}{l}\text { Riparian vegetation } \\
\text { structure }\end{array}$ & $\mathrm{Y}$ & $\mathrm{Y}$ & $\mathrm{Y}$ & $\mathrm{Y}$ & $\mathrm{Y}$ & $\mathrm{Y}$ & $\mathrm{Y}$ & $\mathrm{Y}$ & $\mathrm{Y}$ & $\mathrm{Y}$ & $\mathrm{P}$ & $\mathrm{Y}$ & $\mathrm{Y}$ & $\mathrm{Y}$ & $\mathrm{Y}$ & $\mathrm{Y}$ & ¿? & $\mathrm{N}$ & $\mathrm{P}$ & $\mathrm{N}$ & $\mathrm{Y}$ & $\mathrm{Y}$ & $\mathrm{N}$ & $\mathrm{N}$ & $\mathrm{N}$ & $\mathrm{N}$ \\
\hline & & $\begin{array}{l}\text { Longitudinal } \\
\text { continuity of } \\
\text { riparian vegetation }\end{array}$ & $\mathrm{N}$ & $\mathrm{Y}$ & $\mathrm{Y}$ & $\mathrm{Y}$ & $\mathrm{N}$ & $\mathrm{P}$ & $\mathrm{P}$ & $\mathrm{Y}$ & $\mathrm{Y}$ & $\mathrm{N}$ & $\mathrm{N}$ & $i ?$ & $\mathrm{Y}$ & $\mathrm{Y}$ & $\mathrm{N}$ & $\mathrm{P}$ & ¿? & $\mathrm{N}$ & $\mathrm{Y}$ & $\mathrm{Y}$ & $\mathrm{P}$ & $\mathrm{Y}$ & $\mathrm{P}$ & $\mathrm{N}$ & $\mathrm{N}$ & $\mathrm{N}$ \\
\hline \multirow{3}{*}{\multicolumn{2}{|c|}{ FLOODPLAIN }} & Land uses & $\mathrm{Y}$ & $\mathrm{Y}$ & $\mathrm{N}$ & $\mathrm{Y}$ & $\mathrm{N}$ & $\mathrm{Y}$ & $\mathrm{Y}$ & $\mathrm{Y}$ & $\mathrm{N}$ & $\mathrm{N}$ & $\mathrm{N}$ & $\mathrm{N}$ & $\mathrm{N}$ & $\mathrm{Y}$ & $\mathrm{N}$ & $\mathrm{N}$ & ¿? & $\mathrm{Y}$ & $\mathrm{Y}$ & $\mathrm{Y}$ & $\mathrm{Y}$ & $\mathrm{Y}$ & $\mathrm{N}$ & $\mathrm{N}$ & $\mathrm{Y}$ & $\mathrm{N}$ \\
\hline & & Land uses & $\mathrm{Y}$ & $\mathrm{Y}$ & $\mathrm{N}$ & $\mathrm{Y}$ & $\mathrm{N}$ & $\mathrm{Y}$ & $\mathrm{Y}$ & $\mathrm{N}$ & $\mathrm{N}$ & $\mathrm{N}$ & $\mathrm{N}$ & $\mathrm{N}$ & $\mathrm{Y}$ & $\mathrm{Y}$ & $\mathrm{N}$ & $\mathrm{N}$ & ¿? & $\mathrm{Y}$ & $\mathrm{Y}$ & $\mathrm{Y}$ & $\mathrm{Y}$ & $\mathrm{N}$ & $\mathrm{N}$ & $\mathrm{N}$ & $\mathrm{Y}$ & $\mathrm{Y}$ \\
\hline & & Lateral connectivity & $\mathrm{P}$ & $\mathrm{P}$ & $\mathrm{N}$ & $\mathrm{N}$ & $P$ & $\mathrm{P}$ & $\mathrm{N}$ & $\mathrm{N}$ & $\mathrm{N}$ & $\mathrm{N}$ & $\mathrm{N}$ & $\mathrm{N}$ & $\mathrm{N}$ & $\mathrm{Y}$ & $\mathrm{P}$ & $\mathrm{P}$ & ¿? & $\mathrm{Y}$ & $\mathrm{P}$ & $\mathrm{Y}$ & $\mathrm{Y}$ & $\mathrm{Y}$ & $\mathrm{N}$ & $\mathrm{N}$ & $\mathrm{P}$ & $\mathrm{P}$ \\
\hline
\end{tabular}

